This is an electronic reprint of the original article. This reprint may differ from the original in pagination and typographic detail.

Author(s): Murphy, Jonathan; Malin, Virpi

Title: How Does Dialogue Really Take Place in a Democratic Transition?

Year: $\quad 2015$

Version:

Please cite the original version:

Murphy, J., \& Malin, V. (2015). How Does Dialogue Really Take Place in a Democratic Transition?. In Academy of Management Proceedings 2015 (Article 17250). Academy of Management. Academy of Management annual meeting proceedings. https://doi.org/10.5465/AMBPP.2015.33

All material supplied via JYX is protected by copyright and other intellectual property rights, and duplication or sale of all or part of any of the repository collections is not permitted, except that material may be duplicated by you for your research use or educational purposes in electronic or print form. You must obtain permission for any other use. Electronic or print copies may not be offered, whether for sale or otherwise to anyone who is not an authorised user. 


\title{
HOW DOES DIALOGUE REALLY TAKE PLACE IN A DEMOCRATIC TRANSITION?
}

\author{
JONATHAN MURPHY \\ Cardiff Business School \\ Cardiff University \\ Cardiff, Wales, UK CF10 3EU \\ VIRPI MALIN \\ Jyväskylä University School of Business and Economics, Finland
}

\section{INTRODUCTION}

This paper examines and critically reflects upon the nature of the dialogic processes in the case of a national dialogue in a project of democracy construction. The case deals with development of a new democratic constitution subsequent to Tunisia's Arab Spring revolution of 2011, a process experienced and documented by the first author. We explore how dialogue took place in the constitutional process and how political and social actors engaged with each other during the process of drafting the country's new Constitution that between 2012 and 2014.

As the democratic transition was negotiated largely in the open and through multiple avenues of public debate, the Tunisian case offers a unique insight into the autonomous construction of societal level dialogic processes. The role of the first author enabled to observe the unfolding of the process and gather insights for examining the processes through which dialogue can take place, the barriers to effective participation and the preconditions for engagement, and the stages of development in a dialogic process.

Theoretical interest lies in the preconditions for dialogue, the fundamentals and functions of dialogue, and the questions of power and power asymmetries especially from the deliberative and emancipative perspectives. In this regard we draw particularly on the writings of Freire $(1975 ; 2006)$ and Habermas $(1975 ; 1980 ; 1990)$ on dialogic processes.

Actors enter into dialogic processes bearing the marks of their previous experiences. In the case of countries emerging from dictatorship such as Tunisia, the imprint of authoritarian constraints on free speech and interaction is embedded within society and in social interactions (Moghaddam, 2013). While there have been many studies of the interaction of authoritarianism and personality (Adorno et al., 1950), there has been very little scholarly discussion of the impact and constraints placed upon dialogue when engaged actors have been marked by their passage through dictatorship with its repression of diverse ideas, prohibition of free discussion, and normalization of interpersonal brutality. Overcoming the dictatorial legacy includes not least the challenge of including victim and perpetrator in a democratic dialogue. The paper's exploration of the barriers to dialogue in the post-dictatorship environment identifies the process through which authentic dialogue became decisive in the transitional process's success.

\section{Background}

Since the 1980s there has been a substantial increase in the number of countries in the world governed by putatively democratic systems. The Soviet Union's collapse not only led to the emergence of a number of liberal democracies in Eastern Europe but also reduced 
superpower competition that had led the United States to support authoritarian governments in Latin America, Africa, and Asia as a 'bulwark against communism'. The so-called 'third wave' of democratization resulted in the replacement of overtly authoritarian regimes with a range of different regimes that generally claimed to be 'democracies' - albeit with a variable definition of what that entailed. One region remained largely immune to the democratic shift; this was the Middle East and North Africa. The region, already encountering the challenges of postcolonial state construction, has faced existential crisis since the displacement of the Palestinian population after the establishment of Israel, undergoing a number of important upheavals in the last third of the twentieth century.

Most countries within the Arab region continued to be governed by authoritarian regimes, although limited democratic openings took place in several countries during the 1990s and 2000s. Many of the region's regimes were tacitly supported by the United States and Western European powers for a combination of various reasons. These included; as a bulwark against the dangers of Islamic extremism as evidenced in the developments in Iran and Algeria; in order to secure and assure oil supply to the West from the most productive region in the world; and, as part of Western powers' international politics towards the region that emphasized the security of the Israel state.

With little if any commitment on the part of the West to facilitate or encourage democratization, and indeed on the contrary frequently substantial support to the security apparatus that underpinned most of these regimes, the 2000s were marked by governance stagnation in much of the region. Undemocratic regimes retained sufficient strength to contain sullen and sometimes restive populations. Democratic development advocates were generally pessimistic about the potential for rapid change, and frequently pinned their hopes on supposedly 'reforming' power elites (Ottaway and Hamzawy, eds. 2009; Ottaway and Choucair-Vizoso, eds. 2008; Giddens, 2006), although in retrospect this has been widely criticized as complicity in authoritarianism: "How did we back, use and encourage the brutality of Arab dictators over so many years? To what degree did that cynical encouragement of despots foster the very jihadist rage Western societies sought to curb?"

The Tunisian revolution culminating on January 142011 surprised almost all 'democracy experts', although astute foreign diplomatic observers, whose perspectives were exposed by the WikiLeaks tapes, had for several years been warning of the growing unpopularity of the kleptocratic elite surrounding President Ben Ali (Keller and Star, 2011).

Four years later, the promise of the Arab Spring has transformed into concern about instability and even civil war in some Arab countries, the return of dictatorship in others, and the stalling of reforms in still more. However the Tunisian example continues to progress, the country adopting a new democratic constitution in 2014, and later the same year organizing democratic legislative and presidential elections that resulted in the peaceful transfer of power.

\section{Dialogical Framework}

Historically the concept of dialogue relates to deliberation and emancipation, which means shifting power from the superiors and turning the objects of planning and decisionmaking into the participating subjects. The work of Jürgen Habermas $(1975 ; 1984 ; 1990)$ and Paolo Freire $(1970 ; 2005)$ have been the most influential in current interpretations of dialogue; both being also those who have dealt with the question of power. In spite of similarities in developing approaches that rely on authentic engagement and participation, the dialogues by 
Habermas and Freire have fundamental differences in the process and in addressing the question of power.

Habermasian dialogue is based on his theorizing on communicative action in the ideal speech situation. For Habermas dialogue is seen as means for participatory decision-making, which realizes through the construction of best and most rational arguments. The ultimate goal is to achieve and maintain consensus, which is based on shared values and the ideal of prioritizing mutual good (the commonweal) instead of the pursuit of individual goals. In the ideal situation all participants are equal and capable of producing reasoned argumentation, which means dispelling power asymmetries.

For Freire, dialogue is the encounter between people in order to learn and name the world. Contrary to the Habermasian approach, power and power asymmetries are not embedded. There are always oppressors and oppressed, although not necessarily in a traditional sense. Access to knowledge may differ and those with "better" knowledge may indoctrinate others and try to adjust them to their own reality (see Freire, 2005: 94, 129). Freire states that dialogical encounter cannot take place between antagonists (ibid.). Dialogue is based on sharing knowledge with the purpose of learning from others so that all participants can learn more together than they would individually. Knowledge gained in critical dialogue is then the standpoint for transformation. The outcome - transforming the reality and changing the world for better - is a joint responsibility.

In contrast to the Habermasian ideal of equality as a standpoint, Freirean equality is based on the idea of equal right to "name the world", regardless of the position. Freire has faith in people, which he regards as a priori requirement for dialogue. True dialogue requires critical thinking, which is a source for transformative knowledge. Freire stresses everybody's right to speak their word, to be critical and question the status quo. The word, as an essence of dialogue, has two dimensions, reflection and action, which together mean praxis. Critical reflection is transformative, but transformation does not happen without action. Yet, Freire warns of emphasizing mere action, because then the word is converted to activism, which negates true praxis and precludes dialogue. For Freire, saying the true word means transforming the world. (Freire, 2005: 87-91).

\section{The Tunisian Case}

Tunisia is the only one of the Arab countries to successfully undergo a thorough democratic transformation; there has been no 'domino effect' to support Tunisia's transformation; indeed on the contrary the failure of many of the Arab Spring uprisings has left Tunisia alone in clearly following the path of democratization.

Tunisia explicitly chose perhaps the most difficult road to establish a new democracy; the creating of a democratic framework anchored in a new constitution that would be written from a blank page, by a popularly elected constituent assembly. There was no preliminary 'official understanding' of what the new democracy should be like. So creating the constitution - naming the democracy - meant that the different actors, including representatives of different parties across the ideological spectrum, had the possibility to name the world from their perspective. There was no "truth" which actors needed to accept in order to engage in the dialogue around a new constitution, unlike many participatory processes in which participation effectively entails acceptance of the world as seen by those designing the dialogue (Cooke and Kothari, eds., 2001). This absence of a pre-existing framework at the same time made progression through the 
constitutional process fraught with crises and uncertainty, but also invested the eventual constitutional agreement with an unusually deep authenticity and legitimacy. The process corresponds closely with Freire's vision of a genuine process of collective learning.

Yet, Tunisia is a country with deep divisions about the type of society it should be, with perspectives ranging from radical secularism to fundamentalist Islamist. Thus, whereas recently democratizing countries in some other parts of the world have enjoyed a fairly broad consensus on the type of democratic state that should be established, this was not the case in Tunisia. The challenge of the democratic transition in Tunisia was to move from untrammeled hierarchic hegemony to dynamic and interactive process of decision-making. This endeavor, particularly without external factors rewarding a democratic outcome, required the development through democratic dialogue of a system for democratic decision-making. Thus it was a process that more or less had to be invented as it went along.

The Constitution-drafting process was initially intended to take one year. Six constitutional committees were established, one for each core chapter of the new Constitution. Popular consultations were included in the process, and parliamentarians' committees visited all 24 governorates of the country and gathered citizens' input. A series of drafts were produced and released for public input during 2012 and 2013. There was a passionate ferment of public debate, with the newly free, diverse media reporting all perspectives, disagreements, and rumors.

From the beginning the process was characterized by polarization, and power asymmetries, with different actors each tending to feel that they were the one without power. The Islamists, who had been subjected to thirty years of repression under the old regime, felt that they were threatened by the entrenched political power of representatives of the former regime and its police state. The widespread fear of violence or even a coup d'état actually led to a broadening of the debate beyond the National Constituent Assembly (NCA) and onto the streets. Initially two forms of legitimacy opposed each other; the legitimacy of the elected parliament and the popular legitimacy of the street, which claimed to reflect the original spirit of the 2011 revolution. After several months of blockage, four major Tunisian organizations including the leading trade union central and the main employers association, came together in what became known as the Quartet, and launched a process known as the National Dialogue. The Dialogue initially entailed separate consultations with all the political parties represented in the Assembly, as well as other major social actors. The process of agreeing what the Dialogue would be about, and establishing preconditions for the Dialogue to begin took several months of tense shuttle diplomacy, accompanied by varying levels of street mobilization on both sides, before the different actors were able to even sit down together in the same room and discuss the content of the Dialogue. It was notable that the great bulk of energy was devoted to the establishment of mutual confidence based on respect for the legitimacy of the other rather than on the specific policy content. The points of policy disagreement on the content of the constitution, while significant, assumed a secondary role. All the actors, even those vehemently committed to one camp or another, concurred that 'once we can agree on the terms for a dialogue, the actual constitutional debate can be concluded very quickly'. The core question that had to be addressed was how the different sides could trust each other. Hence, the actual process of dialogue proved to be both inclusive and ultimately extremely effective. Again, the Freirean notion of faith in people was the prerequisite for true dialogue realized in this case.

It was early January 2014 by the time agreement was reached on restarting parliamentary debate on the constitution, on the government's replacement by a technocratic government, and an election process and timetable,. From this point, the process moved quickly and in general 
smoothly. The Assembly established a 'compromise' committee that addressed articles in the proposed constitution that did not have consensus. The committee, included all the parties represented in the Assembly, hammering out agreements, while the Quartet continued holding National Dialogue meetings permitting broader input into points of disagreement in the constitutional process and on broader policy and governance matters. The Assembly made significant changes to the last Constitutional draft which mainly had the effect of strengthening human rights protections. Gender equality provisions in particular were significantly enhanced, setting a progressive example in the region and beyond. After clause by clause voting, the full constitutional draft was voted on January 26 2014, only three weeks after debate had begun in the plenary. The new Constitution was adopted by an overwhelming majority of legislators, from across the political spectrum.

\section{CONCLUSIONS}

There is considerable debate within political philosophy regarding how democracies should operate, and indeed what constitutes democratic dialogue. It has been long understood that for collaborative decision-making to take place, the engaged actors need to interact according to some type of mutuality; in other words where each feels that they are free to contribute to the dialogue and that their contribution inheres in the final decision. The most commonly presented explanation of the desired condition for democratic dialogue within contemporary political philosophy derives from Habermas's proposition of an ideal speech state. However, Habermas has been sharply criticized by critical post-structuralists who argue that the ideal communicative state is a fantasy; interpersonal interactions always entail power and indeed according to Foucault, power is the capillary lifeblood of society. Building from this perspective, Laclau and Mouffe (1985) developed a less ambitious but more dynamic understanding of democratic politics in which the fluidity and dynamism of power relationships underpinned an always imperfect and conditional nature of democratic debate. In this approach, developed through a fusion of Foucauldian, Althusserian, and Gramscian insights, the victorious (the 'hegemonic') perspective is constructed on the basis of conditional and temporary commonalities of interest established not through the victory of an impersonal and commonly acknowledged Reason but rather through a messy and multi-layered process of debate, alliance-building, conflict, brinkmanship and compromise.

The Tunisian democratic transition provides a remarkable and quite unusual example of a societal level dialogic process. The particular conditions in Tunisia in which an open process was able to develop from the aftermath of the 2011 revolution through to adoption of the Constitution in 2014 reflected specificities of Tunisian society, the historical context, the relative absence of external interference, and the absence of internal actors powerful enough to claim power and close down dialogue. These conditions created a kind of laboratory to examine how a democratic system can be constructed through dialogue.

The suspension of the National Constituent Assembly after two political assassinations in 2013 represented a watershed that in retrospect can be seen as the end of the phase of "planned" consensus building (the "Habermasian phase"), and the beginning of unplanned, chaotic, often conflictual but ultimately successful dialogue through mutual naming of the new democratic order (the "Freirean phase"). The 'contained' consultations of the pre July 252013 period, built upon a traditional notion of electoral legitimacy and citizen consultation, had failed to reflect the 
necessity of a democratic order being built through passionate engagement and the genuine forging of common identity.

The real conditions of Tunisia after the revolution were not those where the Habermasian notion of an 'ideal speech state' could be realized. After decades of the shadow of dictatorship, the suppression of mutuality, the fostering of distrust and the heaping of calumny on the Other, Tunisians needed to be engaged with passion that necessarily overflowed the framework of representative democracy and planned consultation; they needed to feel, close-up, the pain, the fears, and the dreams, the humanity of the Other. This could not be achieved through an 'ideal speech state' and communicative reason; implausibly aloof for the construction of a democratic order in a post-revolutionary state.

The Freirean notion does not require an initial ideal state but rather depends upon the engagement of all actors in a sustained interactive process of dialogue which necessarily involves challenges to the authority of each participant. The Freirean model of dialogue recognizes that power imbalance exists in all human interactions and that the dialogic process is about ensuring that everyone is able to speak and feels that their voice is heard. While the originally planned process did involve citizen input, this managed consultation did not reflect the depth of passions and the reality that each side had different ways of 'naming the world' to use Freire's terminology. This difference in naming is particularly important in the Tunisian context where, contrary to other recent democratic transitions such as in Eastern Europe or in South Africa, there are significant differences in vision of the world. Until each side had the opportunity to name its world, it was not possible for them to think about a consensus. The long period of citizen mobilization and dialogic preparation in the second half of 2013 represented essentially the playing out of the naming of the world. It is instructive that with an adequate time allowed for that naming, the actual, formal agreement occurred rather quickly.

Clearly the successful Constitutional process does not resolve or eliminate difference; Tunisians continue to view and name their world differently according to their divergent ideological, religious, and geographical identifications; democratic construction is not a one-time only process. Difference and mistrust remains, and was reflected in polarized debates during the elections of 2014. However once the Constitution was adopted, elections were organized smoothly and transparently before the end of 2014 as prescribed in the Constitution.

Tunisia remains a relatively fragile democracy, with the need to address significant regional inequalities at the same time as facing major economic and fiscal challenges in the context of continuing crisis in Europe, by far its biggest market. The threat from terrorism, as well as civil war in neighboring Libya, remains acute. It is possible some shock will occur that the fledging system cannot sustain. Even if that should turn out to be the case, the experience of the four years since the Tunisian revolution provides an extraordinary wealth of learning on both democratic transition and dialogic processes.

\section{ENDNOTES}

1. The first author of has been an advisor to the Tunisian democratic transition since 2012 . 2. Roger Cohen, "Libyan Closure," New York Times, 7 March 2011.

3. The UGTT trade union central, the UTICA employers' association, the Tunisian Human Rights League, and the Tunisian Bar Association.

\section{REFERENCES AVAILABLE FROM THE AUTHORS}


Copyright of Academy of Management Annual Meeting Proceedings is the property of Academy of Management and its content may not be copied or emailed to multiple sites or posted to a listserv without the copyright holder's express written permission. However, users may print, download, or email articles for individual use. 